\title{
NEW DIMENSIONS OF THE EUROPEAN NEIGHBOURHOOD POLICY: CASE OF ARMENIA
}

\begin{abstract}
The article puts into comparative perspective the EU-Armenia Comprehensive and Enhanced Partnership Agreement and the Treaty on Accession of the Republic of Armenia to the Eurasian Economic Union. It specifically underlines the interplay between the CEPA values and norms discourse and Armenia's membership in Eurasian integration project. It further assesses the effect of the "Velvet Revolution" of 2018 on the country's external policy, stating that it has little chance to cause deviation from the currently dominating multi-vector external course. The article concludes that the Armenian case challenges the EU linear approach to developing relationship with neighbouring countries, being an example of reconciliation of the EU-EAEU political and modernisation agendas. This brings into question the need for a clear vision of the future for both integration projects.
\end{abstract}

Key words: Armenia, EU, Comprehensive and Enhanced Partnership Agreement, European Neighbourhood Policy, South Caucasus

\section{Values and interests dilemma}

European Neighbourhood Policy is aimed at creating a circle of friends around the European Union. On the other hand, it inevitably creates borders and marks neighbouring countries either as a part of the European project, or as outsiders that are not involved. The case of Armenia is specifically significant because it challenges this model, offering instead a non-linear selective partnership format with the EU and the Eurasian Economic Union. This further results in more ambiguity about the exclusiveness of the EU as a normative actor. At the same time, it clearly demonstrates the current absence of a strong modernisation agenda of the Eurasian integration project. Fortunately for Armenia, that is a neighbour to both, the obscurity of long-run objectives of both projects makes it possible to pursue a multi-vector external policy. Thus, Armenia has become a member of the Eurasian Economic Union in 2015 and signed the Comprehensive and Enhanced Partnership Agreement (CEPA) with the EU in 2017.

The Treaty on Accession of the Republic of Armenia to the Eurasian Economic Union offers practically no normative or values agenda, instead focusing on alleged friendship between participating countries and their intention to stimulate Eurasian integration stated in the preamble. ${ }^{1}$ As a consistent pursuer of multi-vector policy, none of the Armenian governments would object to the need to sustain friendly relations with its partners. Still, obviously, the Armenia-EAEU relation is heavily distorted towards strategic partnership between Armenia and Russia, while all the other EUEU members play an almost negligible role in country's economic and political life. Thus, the

(C) Айвазян Анна Cmenановна - научный сотрудник Отдела европейской интеграции Института Европы РАН. Adpec: РФ, 125009, Москва, ул. Моховая, д. 11, стр. 3.E-mail: anna.ayvazyan@ gmail.com.

The article is based on the material prepared for the Second Annual Convention of the Association of European Studies for the Caucasus, 12-13 April 2018.

DOI: http://dx.doi.org/10.15211/vestnikieran420182327

${ }^{1}$ Договор о присоединении Республики Армения к Договору о Евразийском экономическом союзе. Парламент Республики Армения. URL: http://www.parliament.am/library/etm/20142811182417625.pdf (Дата Обращения: 22.08.2018) 
share of Russia in Armenia's external trade with EAEU members comprises more that $95 \%{ }^{2}$. The Armenia's dependence on Russia in economic and military sphere is a rather negative agenda that is so far not anyhow complemented with a shared vision for the future.

Contrary to that, the CEPA agreement identifies a vision for cooperation, stressing mutual commitment and respect for fundamental freedoms, human rights, including the rights of persons belonging to minorities, democratic principles, the rule of law, and good governance. The CEPA values discourse is supported with the reference to the international legal basis for that: namely, principles and provisions of the United Nations Charter, the United Nations Universal Declaration of Human Rights of 1948, the European Convention for the Protection of Human Rights and Fundamental Freedoms of 1950 ("the European Convention on Human Rights") and the Helsinki Final Act of 1975 of the Conference on Security and Cooperation in Europe ("OSCE Helsinki Final Act" $)^{3}$. Thus, the normative agenda of the EU-Armenia relationship is connected to universal declarations and conventions, making it a part of the global picture.

On the other hand, the CEPA agreement acknowledges that internal reforms towards strengthening democracy and the market economy are linked to sustainable conflict settlement. Unfortunately, this argument has proved to be wrong through many years of the EU-Armenia cooperation, resulting in the biggest violation of the ceasefire agreement between Armenia and Azerbaijan in 2016. The considerable problem in this process is inability of two conflict parties, Armenia and Azerbaijan, to reach a peaceful solution over Nagorno-Karabakh conflict. The differentiating ambition in approximation with the EU also plays a role and limits the extent, to which the conditionality principle can be used towards both EU neihbours, Armenia and Azerbajan, in promoting peace and stability in the region.

As Armenia is a part of both European and Eurasian integration projects, it managed to incorporate the European values narrative into its political agenda, at the same time maintaining close relations with the countries of the Eurasian Economic Union. The legal basis of both integration groups does not clash. At the same time, while the Comprehensive and Enhanced Partnership Agreement with the EU offers a vision of Armenia's role globally, the Accession Agreement to the Eurasian Economic Union is only targeted at economic partnership, having no ideational basis. The implication of this is that Armenia has internalised both discourses, choosing the European political model as a modernisation objective to strive for and the Eurasian Economic Union as a strategic partner in more pragmatic dimensions (security and economic cooperation).

\section{Structural reforms or targeted approximation?}

\footnotetext{
${ }^{2}$ Доклад о состоянии взаимной торговли между государствами-членами Евразийского экономического союза. Евразийская экономическая комиссия. URL:

http://www.eurasiancommission.org/ru/act/integr_i_makroec/dep_stat/tradestat/analytics/Documents/report/Report_201 5-2016.pdf (Дата обращения:22.08.2016)

${ }^{3}$ Comprehensive and Enhanced Partnership Agreement. EEAS. URL:

https://eeas.europa.eu/delegations/armenia_en/37967/EU-

Armenia\%20Comprehensive\%20and\%20Enhanced\%20Partnership\%20Agreement\%20(CЕРА) (Дата обращения:
} 22.08.2018)

Научно-аналитический вестник ИЕ РАН, 2018, №4 
While Armenia's membership in the Eurasian Economic Union does not cover as many aspects of mutual cooperation as the Comprehensive and Enhanced Partnership Agreement with the EU does, it is still critical for the country for several reasons. Some of them: dependence on Russian energy resources, decisive role of Russia in Minsk group and Collective Security Treaty Organisation, as well as a considerable number of migrant workers from Armenia in Russia..

The Eurasian Economic Union is not only targeted at economic cooperation between member countries, but also does offer support in infrastructure development and energy cooperation. This is crucial for Armenia, as it does not have a common border with the Eurasian Economic Union, being separated from it by Georgia that is not a part of the project. In practice this means that it is mostly importers that currently benefit from closer approximation of tariffs and standards, as exporters still need to go through the transit procedure that has not become easier. This indicates the importance of any transit routes that would connect Armenia with the Eurasian Economic Union via Georgia, as well as the need for negotiating transit procedure with a non-member country. Currently, transport operators from Armenia got a preferential right to pass through the Upper Lars checkpoint at the Russian-Georgian border. Apart from that, the Armenian electricity market should be connected to that of the Eurasian Economic Union via Georgia in 2019. Most importantly, the price of Russian gas has decreased by $9 \%$ in 2017 compared to $2016^{4}$. Here, the role of Georgia as a transit country becomes of utmost importance, given the crisis of Russian-Georgian relations. Armenia, having a closed border with two other neighboring countries, is mostly susceptible to regional instability that might arise from any kind of Russia- Georgia confrontation.

Having said that, the Armenia's participation in Eurasian Economic Union has acquired very clear perspectives, where all the parties involved have identified their interests and potential mutual benefits. Nevertheless, the project so far seriously lacks humanitarian perspective, it also does not have any ambition to offer a model for political and institutional development.

At the same time, this is what the CEPA agreement is able to promote. While the EU does not seriously influence the resolution of the Nagorno-Karabakh conflict or energy dependence of Armenia, it does aim to strengthen political, economic and institutional stability by approximating state regulations and policies to those of the European Union. This concerns achieving a functioning market economy, transparent state regulation, fight against corruption, etc. More specifically, the EU-Armenia cooperation priorities in 2014-2017 have been: private sector development, public administration reform, justice sector reform ${ }^{5}$.

In theory, both approaches are complementary to each other, bur are seriously reliant on volatile political situation in the region, including EU-Russia relation, the EU and EAEU possible co-

\footnotetext{
${ }^{4}$ Доклад о состоянии взаимной торговли между государствами-членами Евразийского экономического союза. Евразийская экономическая комиссия. URL:

http://www.eurasiancommission.org/ru/act/integr_i_makroec/dep_stat/tradestat/analytics/Documents/report/Report_201 5-2016.pdf (Дата обращения:22.08.2016)

${ }^{5}$ Armenia and the EU. EEAS. URL: https://eeas.europa.eu/delegations/armenia/896/armenia-and-eu_en (Дата обращения:22.08.2018)
} 
operation, relations with Georgia, not undermining the role of media discourses and possible informational confrontation between all the sides involved.

\section{"Velvet Revolution" 2018: the role for the external policy}

Following the attempt of Armenian president Serzh Sargsyan to stay in power in April 2018 and the subsequent mass protests and change of ruling elite, the question about the Armenia's external policy comes as natural. The prime-minister of Armenia Nikol Pashinyan who previously represented the "Elq" oppositional bloc was known for a straightforward pro-European position. The "Elq" has also insisted on quitting the Eurasian Economic Union, initiating a law project on that $^{6}$. Nevertheless, already during the parliamentary hearings Pashinyan insisted that the protests do not threaten the strategic Russia-Armenia relationship, Armenia will keep being a member of the Eurasian Economic Union, at the same time developing relations with the EU and the US. This was further reinforced by his meeting with the Duma PMs on 29 April $^{7}$. The argument about quitting the EAEU was thus used during the political competition game and then was disposed of when the corresponding political forces came to power. The tendency towards multi-vector policy has been sustained, while the protests were mostly inspired by internal agenda: fight against corruption, oligarchy, high level of poverty and consistent suppression of demonstrations by the police.

At the same time, the current political regime and the new political elite are in search for a consolidating idea for Armenian nation. To a high degree it has to do with finding the ways for overcoming drastic economic crisis, identifying priorities for further development and attracting Armenian diaspora to be more involved into the political life of the country. As a consequence, ideational dimension of any partnership could even more reinforce mutual commitment to future cooperation- and this relate to both the European and Eurasian integration.

\section{Conclusions}

Armenian case demonstrates the complexity and non-linear character of a country's involvement into any integration project. It is a constant process of communication and development of joint agenda that needs to correspond to changing interests of all the parties involved.

While the interests/values dilemma has always been a challenge for the EU Neighbourhood policy, it is also a perspective not to be ignored by the Eurasian Economic Union.

Another challenge to further development of the Armenia and the EAEU relation is absence of a common border and Armenia's dependence on Georgia as a transit country. As all the infrastructure projects have Georgia involved in the process, it is critical to minimise the risks of political confrontation.

\footnotetext{
${ }^{6}$ Парламентская фракция «ЕЛК» призвала к выходу Армении из ЕАЭС. URL: www.kavkazuzel.eu/articles/309257/ (Дата обращения:22.08.2018)

${ }^{7}$ Russia-Armenia relations and the April Revolution. Russian International Affairs Council. URL: http://russiancouncil.ru/en/analytics-and-comments/analytics/russia-armenia-relations-and-the-april-revolution/ (Дата обращения: 22.08.2018)
}

Научно-аналитический вестник ИЕ РАН, 2018, №4 
As Armenia is involved in both the European and Eurasian integration projects, the country's ability to maneuver between different actors heavily depends on volatile political situation in the region and indirect influence of EU-Russia relations.

The "Velvet Revolution" that happened in Armenia in April 2018 further reiterates the search for a consolidating idea by the countries that represent the EU and Russia common neighbourhood. This should not be ignored by integration initiatives.

\section{References}

1. Договор о присоединении Республики Армения к Договору о Евразийском экономическом союзе. Парламент Республики Армения. URL: http://www.parliament.am/library/etm/20142811182417625.pdf (Дата Обращения: 22.08.2018)

2. Доклад о состоянии взаимной торговли между государствами-членами Евразийского экономического союза. Евразийская экономическая комиссия. URL: http://www.eurasiancommission.org/ru/act/integr_i_makroec/dep_stat/tradestat/analytics/Do cuments/report/Report_2015-2016.pdf (Дата обращения:22.08.2016)

3. Comprehensive and Enhanced Partnership Agreement. EEAS. URL: https://eeas.europa.eu/delegations/armenia_en/37967/EU-

Armenia\%20Comprehensive\%20and\%20Enhanced\%20Partnership\%20Agreement\%20(CEPA) (Дата обращения: 22.08.2018)

4. Armenia and the EU. EEAS. URL: https://eeas.europa.eu/delegations/armenia/896/armeniaand-eu_en (Дата обращения:22.08.2018)

5. Парламентская фракция «Елк» призвала к выходу Армении из EAЭC. URL: www.kavkaz-uzel.eu/articles/309257/ (Дата обращения:22.08.2018)

6. Russia-Armenia relations and the April Revolution. Russian International Affairs Council. URL:

http://russiancouncil.ru/en/analytics-and-comments/analytics/russia-armenia-relations-andthe-april-revolution/ (Дата обращения: 22.08.2018)

DOI: http://dx.doi.org/10.15211/vestnikieran420182327 